\title{
RELATIONSHIP BETWEEN SELF- CONCEPT AND MENTAL ALERTNESS AMONG B.ED., TEACHER-TRAINEES IN MADURAI DISTRICT
}

\author{
Dr.J.Kamatchi Eswaran, \\ Assistant Professor of Commerce, \\ V.H.N. Senthi Kumara Nadar College (Autonomous), Virudhunagar. \\ R.Sivajothi, \\ Assistant Professor Management Studies, \\ V.H.N. SenthiKumara Nadar College (Autonomous), Virudhunagar.
}

\begin{abstract}
Education is that process by which an individual freely develops his selfaccording to his nature in a free and uncontrolled environment. In this way, education is a lifelong process. Education is a means for the development of balanced all-round harmonious development of personality. Personality includes not only body and mind, but also spirit. In this research paper, the researcher wants to know the level of self concept and mental awareness among the B,ED Teacher - Trainees. Also the researcher wants to find the association between the demographic variables and self - concept, mental alertness by using Chi - Square test.
\end{abstract}

Key words: Self - Concept, Mental Alertness, Level of Self-Concept, Level of Mental Alertness

\section{INTRODUCTION}

Education, in the broader sense, is transmission of life by the living, to the living, through living and for living. Education is a means for the development of balanced all-round harmonious development of personality. Personality includes not only body and mind, but also spirit. Education is the total development of the personality. Education consists of all those experiences, which affect the individual from birth till death.

Teachers recognize that many students find it difficult to progress academically. This may not be to a low IQ or inability to work hard, but merely because these students have low confidence levels, low self-concept and lack of motivation. This is especially so in grade nine students who are faced with making decision about their future. Students are therefore faced with questions about themselves and their abilities. The researchers suggested that students, who do not perform well academically, might have a low self-concept. When students with a low self-concept approach a decision about subjects, they may make a subject selection that could influence the rest of their future negatively.

\section{DEFINITION OF SELF-CONCEPT}

One's self-concept is a collection of beliefs about oneself that includes such things as academic performance, gender roles and sexuality, racial identity and many others. The self-concept is not restricted to the present as it includes past and future selves. Self-concept is perhaps the single most important attribute and the key to understand the behavior of an individual's self-concept is a critical face of his/her personality. The role of self-concept as a determent of human behavior and its acceptance as a concise measure of personality is increasingly realized. In this study self-concept is defined as the total/integrated perception of themselves with respect to their physical, social, and academic aspects.

Purkey, (1998), "Self-concept is the cognitive or thinking aspect of self (related to one's self-image) and generally refers to the totality of a complex, organized, and dynamic system of learned beliefs, attitudes and opinions that each person holds to be true about his or her personal existence". 


\section{DEFINITION OF MENTAL ALERTNESS}

The human individual has several points of uniqueness and superiority over the animals, the most important of which is Mental Alertness success. It leads to success in one's profession, social adjustment, possession of general information. For precise measurement many of the human characteristics like height, weight, visual acuity, auditory acuity, etc are able to measure. But the same the General Mental alertness cannot be measured accurately. Nature of mental alertness is to be inferred from the way a person behaves, the way he thinks, reasons and acts. Mental Alertness is to be assessed by judging one's ability to learn, capacity to adapt to nest environments and efficiency to solve problems. Mental alertness defined as "an expression of the extent developed achieved by the individual, stated in terms of the performance that can be expected at any given age".

\section{REVIEW OF LITERATURE}

The followings are the reviews of related studies which were conducted in India and Abroad.

Sarath, S.Williams (2000) made an investigation of the self-concept of teachers, working in Tamilnadu who are undergoing M.Ed., course through Distance Education in Annamalai University. Moshin's self-concept inventory was administered to a sample of 125 Teachers. Major findings revealed that there is no significant difference between selfconcept of men and women teachers and there is no significant difference between teachers belonging to forward casters and those belonging to other casters in respect of their self-concept.

Srivastava (2000) made an attempt to study the self concept and sex role among single and married women. A sample of 220 single and 220 married women were selected. All were educated and belonged to urban area. The results indicated that single women had lower self-concept than married women. The correlation between self-concept and sex role was non-significant.

Pujar, L.and Gaonkar. V (2000) analyzed the influence of age and type of family of selfconcept of adolescent belonging to high and low achievers group. The study was carried out on a sample of 284 of age group 14-18 years consisting of 142 high achievers and 142 low achievers, from English medium high school of Dharwad city. The result of the study indicated that the mode of expression of self-concept among both high and low achieving adolescents improved with age. It also revealed that the self-concept of students from nuclear family was higher than the joint family among both low and high achieving adolescents.

Rothi, Despina M.; et al (2001) conducted a study on the front line: "Teachers as active observers of pupils mental alertness" here is a growing expectation that schoolteachers should not only act as educators by delivering the national curriculum, but also be more involved as their one mental alertness professionals. In this role they are expected to assume some responsibility in the early identification of children's mental alertness problem and to refer these children for appropriate support as required. "together we stand": the commissioning, role and management of child and adolescent mental alertness services". London, UK, in this paper, we examine teacher's experiences in light of this expectation and in the context of greater inclusion. Our findings indicate a widespread perception that teacher feel inadequately prepared to manage pupils with mental alertness needs. The findings are discussed with reference to the changing role of the teacher, current education policy and teacher training.

Dosesel, Darrel P,;(2002) conducted a study on "A central dilemma in the mental alertness sector: Structural Imbalance" This study demonstrates the dimensions of structural imbalance in Australia's mental alertness sector by recourse to the 1997 Australian bureau of statistics national surveys of mental alertness and wellbeing. This study examines the concept by reference to the Australian Government's announced COAG initiative (April 2006), and state government responses (July 2006). The two dimensions of structural imbalance are, first, that some people with no clinical mental illness consume mental health services and, second, that other people have clinical manifestation of mental illness do not consume mental health services, the present study shows how the situations coexist. "Throwing money" at the pre-existing structures may do nothing to address the structural imbalance problem. Remedies are discussed by reference undertaken in the British National Health Service in recent years.

Prospero, (2006) studied on "sex-symmetric Effects of Coercive Behaviors on Mental Alertness" the present study tested a section of the model of coercion in intimate partners violence (IPV) by investigating the relationships among coercion, IPV and mental alertness symptoms. The study's sample consisted of 573 culturally diverse university students who completed a survey that measured past IPV victimization, coercive behaviors, and mental alertness symptoms. Structural equation modeling analyses revealed that coercion was a stronger predictor of adverse mental alertness symptoms than 


\section{International Journal of Engineering Applied Sciences and Technology, 2020 Vol. 5, Issue 2, ISSN No. 2455-2143, Pages 210-216 \\ Published Online June 2020 in IJEAST (http://www.ijeast.com)}

was IPV victimization. In addition, the study found that the adverse effect of coercive behaviors on mental alertness symptoms was stronger among male victims of IPV than among female IPV victims.

\section{NEED FOR THE PRESENT STUDY}

The extent to which an individual's urges and interests are satisfied is basic to the kind of emotional experience that is likely to result. A person whose pattern of life runs smoothly, whose reasonable urges and desires meet with fulfillment and who interests are achieved successfully tends to be emotionally stable and to enjoy life. If however his urges, desires or interests are frustrated, either because of lack of ability to satisfy them or because of unfavorable environment condition his emotional experience may follow patterns of maladjustment.

A mental alertness and self-concept are important personality traits, it is essential for a teacher trainee to see to it that his/her emotions can highly influence the personality of their future students. In the present study the investigator evaluates the mental alertness and self-concept of B.Ed., teacher trainees and how it influences their academic achievements and future life perspective.

\section{OBJECTIVES OF TE STUDY}

- To find out the level of self-concept and mental alertness among B.Ed., teachertrainees.

- To find out the association between mental alertness and demographic variables like gender, age, type of management, subject studied, father's education, family income, and locality.

- To find out the association between level of self-concept and demographic variables like gender, age, type of management, subject studied, father's education, family income, and locality. To find out the association between level of self-concept and level of Mental awareness among respondents.

\section{RESEARCH METHODOLOGY}

\section{SAMPLING METHOD}

The 200 B.Ed., teacher trainees were taken for the study of which 50 from Government Colleges, 50 from government aided colleges and 100 from private colleges in Madurai District. Convenient sampling method was applied to select the respondents.

\section{PRIMARY DATA}

In order to fulfill the objectives, a sample study was undertaken by using a well-framed questionnaire that was duly filled by the respondents.

\section{SECONDARY DATA}

The primary data were supplemented by a spate of secondary sources of data. Further, the secondary data were also collected from various leading journals, books and websites.

ANALYSIS AND INTERPRETATION OF DATA

TABLE- 1

DEMOGRAPHIC FACTORS WISE CLASSIFICATION OF RESPONDENTS

\begin{tabular}{|l|l|l|l|}
\hline \multicolumn{2}{|c|}{} & $\begin{array}{l}\text { No. of } \\
\text { Respondents }\end{array}$ & Percentage \\
\hline \multirow{4}{*}{ Gender } & Male & 100 & 50 \\
\cline { 2 - 4 } & Female & 100 & 50 \\
\cline { 2 - 4 } & Total & $\mathbf{2 0 0}$ & $\mathbf{1 0 0}$ \\
\hline \multirow{4}{*}{ Age } & $20-21$ Years & 58 & 29 \\
\cline { 2 - 4 } & $22-24$ Years & 97 & 48.3 \\
\cline { 2 - 4 } & Above 24 years & 45 & 22.7 \\
\cline { 2 - 4 } & Total & $\mathbf{2 0 0}$ & $\mathbf{1 0 0 . 0 0}$ \\
\hline \multirow{4}{*}{ Locality } & Language & 61 & 30.7 \\
\cline { 2 - 4 } & Science & 82 & 40.7 \\
\cline { 2 - 4 } & Arts & 57 & 28.6 \\
\cline { 2 - 4 } & Total & $\mathbf{2 0 0}$ & $\mathbf{1 0 0 . 0 0}$ \\
\hline & Urban & 139 & 69.3 \\
\cline { 2 - 4 } & Rural & 61 & 30.7 \\
\hline
\end{tabular}


International Journal of Engineering Applied Sciences and Technology, 2020 Vol. 5, Issue 2, ISSN No. 2455-2143, Pages 210-216

Published Online June 2020 in IJEAST (http://www.ijeast.com)

\begin{tabular}{|c|c|c|c|c|c|}
\hline \multirow{5}{*}{$\begin{array}{l}\text { Monthly Family } \\
\text { Income }\end{array}$} & \multicolumn{2}{|l|}{ Total } & 200 & \multicolumn{2}{|l|}{100.00} \\
\hline & \multicolumn{2}{|l|}{ Upto Rs. $1,00,000$} & \multicolumn{2}{|l|}{108} & 54 \\
\hline & \multicolumn{2}{|l|}{ Rs. $1,00,000$ - Rs. $2,00,000$} & 52 & \multicolumn{2}{|l|}{26} \\
\hline & \multicolumn{2}{|l|}{ Above Rs. 2,00,000 } & 40 & \multicolumn{2}{|l|}{20} \\
\hline & \multicolumn{2}{|l|}{ Total } & 200 & \multicolumn{2}{|l|}{100.00} \\
\hline \multirow{4}{*}{$\begin{array}{l}\text { Type of } \\
\text { Management }\end{array}$} & \multicolumn{2}{|l|}{ Government } & 66 & \multicolumn{2}{|l|}{33.33} \\
\hline & \multicolumn{2}{|l|}{ Aided } & 67 & \multicolumn{2}{|l|}{33.33} \\
\hline & \multicolumn{2}{|l|}{ Private } & 67 & \multicolumn{2}{|l|}{33.34} \\
\hline & \multicolumn{2}{|l|}{ Total } & 200 & \multicolumn{2}{|l|}{100.00} \\
\hline \multirow{4}{*}{$\begin{array}{l}\text { Father's } \\
\text { Educational } \\
\text { Qualification }\end{array}$} & \multicolumn{2}{|l|}{ Uneducated } & 78 & \multicolumn{2}{|l|}{39} \\
\hline & \multicolumn{2}{|l|}{ School level } & 63 & \multicolumn{2}{|l|}{31.7} \\
\hline & \multicolumn{2}{|l|}{ Graduate } & 59 & 29.3 & \\
\hline & Total & & 200 & 100.00 & \\
\hline ource: Primary data & & & & & \\
\hline From the above ta & le, it is clear that both the & 1. & Low & 51 & 25.7 \\
\hline $\begin{array}{l}\text { and female responde } \\
\text { group among the resp }\end{array}$ & $\begin{array}{l}\text { ts are equal. The majority } \\
\text { ndents is between } 22 \text { and }\end{array}$ & 2. & Moderate & 91 & 45.6 \\
\hline ears, followed by th & group of $20-21$ years & 3. & High & 58 & 28.7 \\
\hline $\begin{array}{l}\text { ctively. Only } 28.6 \\
\text { studied Arts subjects }\end{array}$ & $\begin{array}{l}\text { ercent of the respondents } \\
\text { Most of the respondents }\end{array}$ & & Total & 200 & 100. \\
\hline
\end{tabular}
(69.3 per cent) live in urban locality. The monthly income wise analysis of the data of sample respondents reveals that, 54 percent of the respondents have monthly income of up to Rs $1,00,000$. Majority of the respondent's (39 percent) fathers are uneducated.

ABLE - 2

Level of self-concept of the Respondents

\begin{tabular}{|c|c|c|c|}
\hline S.no & $\begin{array}{c}\text { Level of self- } \\
\text { concept }\end{array}$ & $\begin{array}{c}\text { No. of } \\
\text { Respondents }\end{array}$ & Percentage \\
\hline 1. & Low & 55 & 27.7 \\
\hline 2. & Moderate & 93 & 46.7 \\
\hline \multirow[t]{2}{*}{3.} & High & 52 & 25.6 \\
\hline & Total & \begin{tabular}{|l|l}
200 \\
\end{tabular} & 100.0 \\
\hline
\end{tabular}

Out of the 200 respondents surveyed, 22.7 percent of the respondents possessed low level of self-concept and 46.7 percent of the respondents possessed moderate level of self-concept and the remaining 25.6 percent of the respondents possessed high level of self-concept.

TABLE -3

Level of Mental Alertness of the respondents

\begin{tabular}{|l|lr|l|l|}
\hline S.No & $\begin{array}{l}\text { Level of } \\
\text { mental } \\
\text { alertness }\end{array}$ & $\begin{array}{l}\text { No. of } \\
\text { Respondents }\end{array}$ & Percentage \\
\hline
\end{tabular}

From the above table, 25.7 percent of the respondents possessed low level of mental alertness, 45.6 percent of the respondents possessed moderate level of mental alertness and the remaining 28.7 percent of the respondents possessed high level of mental alertness.

\section{ASSOCIATION BETWEEN DEMOGRAPHIC VARIABLES AND LEVEL OF SELF - CONCEPT AMONG RESPONDENTS}

In order to find the association between the demographic variables such as gender, age, type of management, subjects studied, father's educational qualification, family income and locality of the respondents and the level of Self - Concept, the following hypothesis has been framed.

Ho: There is no significant association between the Demographic variables and the Level of Self - Concept among the respondents.

$\mathrm{H}_{1}$ : There is significant association between the Demographic variables and the Level of Self Concept among the respondents.

With the view to find the association between the Demographic variables and the Level of Self - Concept among the respondents, Chi - Square test is used. The result of the test is shown in the following table. 
TABLE -4

\begin{tabular}{|c|c|c|c|c|c|}
\hline S.No & Demographic Variable & $\begin{array}{c}\text { Calculated Chi }- \\
\text { Square Value }\end{array}$ & P Value & $\begin{array}{c}\text { Level of } \\
\text { Significance }\end{array}$ & Remarks \\
\hline 1 & Gender & 0.859 & .092 & 0.05 & Ho Accepted \\
\hline 2 & Type of Management & 9.044 & .118 & 0.05 & Ho Accepted \\
\hline 3 & Subject Studied & 3.789 & .111 & 0.05 & Ho Accepted \\
\hline 4 & $\begin{array}{c}\text { Father's Educational } \\
\text { Qualification }\end{array}$ & 2.925 & .179 & 0.05 & Ho Accepted \\
\hline 5 & Family Income & 4.320 & .124 & 0.05 & Ho Accepted \\
\hline 6 & Locality & 2.972 & .168 & 0.05 & Ho Accepted \\
\hline 7 & Age & 6.074 & .132 & 0.05 & Ho Accepted \\
\hline
\end{tabular}

From the above table, the Chi - Square test reveals that the calculated $\mathrm{P}$ value for all the variables are greater than .05. So the null hypothesis is accepted at $5 \%$ level of significance. So the null hypothesis holds good that, there is no significant association between the demographic variables such as gender, age, type of management, subjects studied, father's educational qualification, family income, locality of the respondents and the Level of Self Concept among the respondents.

\begin{tabular}{lcr}
\multicolumn{2}{c}{ ASSOCIATION } & BETWEEN \\
DEMOGRAPHIC & VARIABLES AND LEVEL \\
OF MENTAL & ALERTNESS AMONG \\
RESPONDENTS &
\end{tabular}

In order to find the association between the demographic variables such as gender, age, type of management, subjects studied, father's educational qualification, family income and locality of the respondents and the level of Mental alertness, the following hypothesis has been framed.

Ho: There is no significant association between the Demographic variables and the Level of Mental alertness among the respondents.

$\mathrm{H}_{1}$ : There is significant association between the Demographic variables and the Level of Mental alertness among the respondents.

With the view to find the association between the Demographic variables and the Level of Mental alertness among the respondents, Chi Square test is used. The result of the test is shown in the following table.

TABLE - 5

\begin{tabular}{|c|c|c|c|c|c|}
\hline S.No & Demographic Variable & $\begin{array}{c}\text { Calculated Chi }- \\
\text { Square Value }\end{array}$ & P Value & $\begin{array}{c}\text { Level of } \\
\text { Significance }\end{array}$ & Remarks \\
\hline 1 & Gender & 17.420 & .003 & 0.05 & Ho Rejected \\
\hline 2 & Type of Management & 45.033 & .000 & 0.05 & Ho Rejected \\
\hline 3 & Subject Studied & 1.901 & .121 & 0.05 & Ho Accepted \\
\hline 4 & $\begin{array}{c}\text { Father's Educational } \\
\text { Qualification }\end{array}$ & 8.233 & .155 & 0.05 & Ho Accepted \\
\hline 5 & Family Income & 11.545 & .004 & 0.05 & Ho Rejected \\
\hline 6 & Locality & 1.601 & .136 & 0.05 & Ho Accepted \\
\hline 7 & Age & 7.345 & .183 & 0.05 & Ho Accepted \\
\hline
\end{tabular}




\section{International Journal of Engineering Applied Sciences and Technology, 2020 \\ Vol. 5, Issue 2, ISSN No. 2455-2143, Pages 210-216 \\ Published Online June 2020 in IJEAST (http://www.ijeast.com)}

From the above table, the Chi - Square test reveals that the calculated $\mathrm{P}$ value for the variables subject studied, father's educational qualification, locality and age are greater than .05 . So the null hypothesis is accepted at $5 \%$ level of significance. So the null hypothesis holds good that, there is no significant association between the demographic variables subject studied, father's educational qualification, locality, age of the respondents and the Level of Mental alertness among the respondents.

From the above table, the Chi-Square test reveals that the calculated $\mathrm{P}$ value for the variables gender, type of Management and family income are less than .05 . So the null hypothesis is rejected at $5 \%$ level of significance. So the null hypothesis does not holds good that, there is significant association between the demographic variables gender, type of Management, family income of the respondents and the Level of Mental alertness among the respondents.

\section{ASSOCIATION BETWEEN LEVEL OF MENTAL ALERTNESS AND LEVEL OF SELF - CONCEPT AMONG RESPONDENTS}

In order to find the association between the level of Mental alertness and the level of Self - Concept, the following hypothesis has been framed.

Ho: There is no significant association between the level of Mental alertness and the level of Self - Concept among the respondents.

$\mathrm{H}_{1}$ : There is significant association between the level of Mental alertness and the level of Self - Concept among the respondents.

With the view to find the association between the level of Mental alertness and the level of Self - Concept among the respondents, Chi - Square test is used. The result of the test is shown in the following table.

TABLE -6

\begin{tabular}{|c|c|c|c|c|c|}
\hline S.No & Variable & $\begin{array}{c}\text { Calculated Chi }- \\
\text { Square Value }\end{array}$ & P Value & $\begin{array}{c}\text { Level of } \\
\text { Significance }\end{array}$ & Remarks \\
\hline 1 & $\begin{array}{c}\text { Level of Mental alertness and Self }- \\
\text { Concept }\end{array}$ & 34.526 & .000 & 0.05 & Ho Rejected \\
\hline
\end{tabular}

From the above table, the Chi - Square test reveals that the calculated $\mathrm{P}$ value for the association between the level of Mental alertness and Self - Concept is less than .05. So the null hypothesis is rejected at $5 \%$ level of significance. So the null hypothesis does not holds good that, there is significant association between the level of Mental alertness and the level of Self - Concept among the respondents.

\section{CONCLUSION AND ACKNOWLEDGEMENT}

Self -concept is influenced by many factors like, one's home environment, school environment, socio economic status level, peer group, etc., The adolescence should be viewed as having an opportunity for achieving a realistic, stable, socially acceptable and personally satisfying self-concept. Adolescents need experience that helps them to move towards others with friendliness. They need to understand their development and move towards others with friendliness. They need to understand their development and take pride in the growth of their wisdom, status, human relations and specific skills.

The Chi - Square test reveals that there is no significant association between the demographic variables such as gender, age, type of management, subjects studied, father's educational qualification, family income, locality of the respondents and the Level of Self - Concept among the respondents.

The human individual has several points of uniqueness and superiority over the animals, the most important of which is Mental Alertness success. It leads to success in one's profession, social adjustment, possession of general information. For precise measurement many of the human characteristics like height, weight, visual acuity, auditory acuity, etc are able to measure.

The Chi - Square test reveals that, there is no significant association between the demographic variables subject studied, father's educational qualification, locality, age of the respondents and the Level of Mental alertness among the respondents.

The Chi - Square test reveals that there is significant association between the demographic variables gender, type of Management, family income of the respondents and the Level of Mental alertness among the respondents.

The Chi - Square test also reveals that, there is significant association between the level of Mental alertness and the level of Self - Concept among the respondents.

Mental Alertness is to be assessed by judging one's ability to learn, capacity to adapt to nest environments and efficiency to solve problems. A mental alertness and selfconcept are important personality traits, it is essential for a teacher trainee to see to it that his/her emotions can highly influence the personality of their future students.

\section{REFERENCES}

1) Anderson \& Poole, w. (1970). "Optimal choice of Monetary Policy Instruments in a Simple Stochastic Macro Moder", The Quarterly Journal of Economics, MIT press, Vol:84(2): (pp.197-216) 
2) Antony. A (1972) the effect of T-group process and study skill training of self-confidence levels of economic opportunity fund in college freshmen and found in the International Abstracts. (pp. 3839)

3) Baker, Larry.D (1973), Blindness and social behavior need for research, new outlook for the blind as found in the international abstracts. (pp.315-321)

4) Kortez, D.S (1991)," Prevention-centered science in mental alertness", American Journal of community Pssychology, Vol:19(4), (pp.453-458)

5) Frank, R.G., \& MeGuire, T.G. (1995), "Estimating costs of mental alertness and substance abuse coverage" Health Affairs, Vol:14(3), (pp.102-115)

6) Inglehart, J.K. (1996), " Managed care and Mental Alertness", The New England Journals of Medicine, Vol:334 (2), (pp.131-135)

7) Inglehart, J.K. (1996), " Managed care and Mental Alertness", The New England Journals of Medicine, Vol:334 (2), (pp.131-135)

8) Buck, J.A., \& Umland, B (1997), “ Covering mental alertness and substance abuse services" Vol: 16(4), (pp.120-126)

9) Deo.P, Sharma Sager (1997), "Relationship between self-concept and anxiety" Journal of Psychology Research Vol:15 (pp63-65)

10) Barooah. $\mathrm{S}$ and Phunkan.M(1999): "A comparative study of self-concept of orphan children with natural parents." Indian psychological Review Vol 32, No.2 August 1999. (pp. 74-78)
11) Bain, S.K \& Bell, S.M (2004), "Social SelfConcept, Social Attributes, and Peer, Relationships in Fourth, Fifth and Sixth Graders who, are Gifted compared to High Achievers" Gifted Child Quarterly, Vol: 48(3): (pp.167-178)

12) Mandeep Kaur and Shilipi Kohli (2006): Shyness of self-concept among High and how socio economic status Adolescents, Journal of community Guidance \& Researrch, Nov-2006, Vol. 23-No.3 (pp. 316-323).

13) Ahmavaara, \& Houston. (2007). The Effects of selective self-concept on adolescents' Academic Aspiration; An Examination of Dweck's selftheory. British Journal of Educational Psychology, 77(3): (pp.613-632)

14) Elana,L.B., Anastasia K., Jessica R.T.,Nancy I. H \&Effie. K.(2007). Severity of Academic Achievement and Social skills Deficits. Candidate Journal of Education, 30(3): (pp.911-930)

15) Chiniwar,p.s.(2012).A study of self-Concept in relation with Academic achievement of secondary school of Bagalkot District. Internationa multidisciplinary e-journal,1(7): (pp. 26-33)

16) Carola, L \& Carsten, J \&in Karl-Heinz, A. (2012), "Longitudinal assessment of elementary school students social self-concept in relation to social preference", Journal for Educational Research online, Vol:4(1): (pp.47-72)

17) Dambudzo.I.I.,\&schulze,s.(2013), "The relationship between learner self- concept and academic achievement in secondary schools in zimbabwe" Prim.Res.Edu. Vol: 3(2) (pp.413-436). 